\title{
NME5 Gene
}

National Cancer Institute

\section{Source}

National Cancer Institute. NME5 Gene. NCI Thesaurus. Code C92502.

This gene may play a role in apoptosis and spermatogenesis. 